\title{
Evaluation of an Indirect Immunoperoxidase Test for Identification of Acholeplasma and Mycoplasma
}

\author{
By ANNA A. POLAK-VOGELZANG, RIEN HAGENAARS \\ AND J. NAGEL \\ Laboratory for Control of Bacterial Vaccines and Laboratory for Immunochemistry, \\ Rijks Instituut voor de Volksgezondheid, P.O. Box 1, Bilthoven, The Netherlands
}

(Received 2 November 1977; revised 3 January 1978)

\begin{abstract}
Four acholeplasma, 11 animal mycoplasma (mostly bovine) and 7 human mycoplasma types were examined using the indirect immunoperoxidase (IP), indirect immunofluorescence (IF) and growth inhibition (GI) tests to compare the sensitivity and specificity of these tests for the identification of Mycoplasmatales. The IP and IF tests were applied to unfixed colonies on agar blocks. Colonies of Acholeplasma laidlawii, Acholeplasma modicum, Mycoplasma agalactiae and Mycoplasma bovis showed a bright yellow autofluorescence in the IF test making it inapplicable in these cases. The IP test was as specific as the GI test and more specific than the IF test. In the IP test, cross-reactions were only found between $M$. agalactiae and $M$. bovis strains, two types originally considered to be related to each other. Crossreactions between these organisms were not seen in the GI test. With one exception, the IP test was also found to be more sensitive than the GI test and as sensitive as the IF test; thus for two Acholeplasma axanthum antisera the IP test was inferior to the IF and GI tests with A. axanthum strains. A close relationship was found in the IP and IF tests between Mycoplasma mycoides strain Gladysdale and the unclassified bovine group 7 strain N29. The results of the IP test were much easier to read than those of the IF tests. Thus colonies treated with homologous antiserum became dark brown and, in mixed cultures, could be readily distinguished from heterologous colonies using a light microscope. All controls were negative and strains isolated from cattle, cell cultures, humans and monkeys were easily identified.
\end{abstract}

\section{INTRODUCTION}

The simplest technique for the identification of Mycoplasmatales is the growth inhibition test on agar (Edward \& Fitzgerald, 1954; Huysmans-Evers \& Ruys, 1956; Clyde, 1964); this is very specific and requires antisera with a high antibody titre and pure cultures. Cloning either via fluid medium or via agar will not always result in pure cultures. This has been demonstrated in the immunofluorescence test which can be applied to primary isolates on agar (Del Giudice, Robillard \& Carski, 1967) or to cell cultures (Carski \& Shepard, 1961; Malizia, Barile \& Riggs, 1961). The indirect test with unfixed colonies on agar blocks is very specific (Rosendal \& Black, 1972) but some acholeplasma types show a pronounced autofluorescence which hampers the discrimination between positive and negative reactions (Potgieter \& Ross, 1972).

In this paper the application of an indirect immunoperoxidase test for the identification of unfixed colonies is described. The specificity and sensitivity of this test are compared with those of the indirect immunofluorescence and growth inhibition tests. 
Table 1. List of reference types and strains

\begin{tabular}{|c|c|c|c|c|}
\hline Type & Strain & $\begin{array}{c}\text { Code } \\
\text { no. }\end{array}$ & $\begin{array}{l}\text { Antiserum } \\
\text { prepared }\end{array}$ & Source \\
\hline Acholeplasma axanthum & $\begin{array}{l}\text { s743 } \\
\text { KN349 }\end{array}$ & $\begin{array}{l}\text { a1 } \\
\text { a6 }\end{array}$ & $\begin{array}{l}+ \\
+\end{array}$ & $\begin{array}{l}\text { NCTC } \\
\text { Own isolation (bovine) }\end{array}$ \\
\hline A. granularum & BTs39 & $\mathrm{a} 2$ & + & ATCC* \\
\hline A. laidlawii & $\begin{array}{l}\text { PG8A } \\
\text { PG9B } \\
\text { KN571 } \\
\text { GMK }\end{array}$ & $\begin{array}{l}\text { a3 } \\
\text { a4 } \\
\text { a7 } \\
\text { a8 }\end{array}$ & $\begin{array}{l} \pm \\
- \\
-\end{array}$ & $\begin{array}{l}\text { NCTC* } \\
\text { NCTC* } \\
\text { Own isolation (bovine) } \\
\text { Own isolation (cell culture) }\end{array}$ \\
\hline A. modicum & Squire & a5 & + & NCTC \\
\hline Mycoplasma agalactiae & PG2 & b1 & + & NCTC* \\
\hline M. alkalescens & PG51 & b2 & + (i.v.) & NCTC \\
\hline M. arginini & G230 & b3 & + & NCTC \\
\hline M. bovigenitalium & $\begin{array}{l}\text { PG11 } \\
\text { RN117 }\end{array}$ & $\begin{array}{l}\text { b4 } \\
\text { b13 }\end{array}$ & $\begin{array}{l}+ \\
-\end{array}$ & $\begin{array}{l}\text { NCTC* } \\
\text { Own isolation (bovine) }\end{array}$ \\
\hline M. bovirhinis & PG43 & b5 & + & NCTC* \\
\hline M. bovis & $\begin{array}{l}\text { Donetta } \\
\text { KN186 } \\
\text { H16 }\end{array}$ & $\begin{array}{l}\text { b6 } \\
\text { b7 } \\
\text { b14 }\end{array}$ & $\begin{array}{l}+ \\
+(\mathrm{i} . v .) \\
-\end{array}$ & $\begin{array}{l}\text { NCTC* } \\
\text { Own isolation (bovine) } \\
\text { Hartman, Utrecht }\end{array}$ \\
\hline M. bovoculi & $\begin{array}{l}\text { M165/69 } \\
\text { U28 }\end{array}$ & $\begin{array}{l}\mathrm{b} 8 \\
\mathrm{~b} 9\end{array}$ & $\overline{+}$ (i.v.) & $\begin{array}{l}\text { NCTC } \\
\text { Own isolation (bovine) }\end{array}$ \\
\hline M. equirhinis & $\begin{array}{l}\text { M } 432 / 72 \\
\text { RN19 }\end{array}$ & $\begin{array}{l}\text { b10 } \\
\text { b15 }\end{array}$ & \pm & $\begin{array}{l}\text { NCTC } \\
\text { Own isolation (bovine) }\end{array}$ \\
\hline M. mycoides & $\begin{array}{l}\text { Gladysdale } \\
\text { PP }\end{array}$ & $\begin{array}{l}\text { b11 } \\
\text { b16 }\end{array}$ & $\begin{array}{l}+ \\
-\end{array}$ & $\begin{array}{l}\text { Australia*† } \\
\text { Durel, Paris* }\end{array}$ \\
\hline Mycoplasma sp. Leach group 7 & $\mathrm{~N} 29$ & b12 & + & NCTC \\
\hline M. buccale & $\begin{array}{l}\text { PG41 } \\
\text { CynK1 }\end{array}$ & $\begin{array}{l}\mathrm{c} 1 \\
\mathrm{c} 11\end{array}$ & $\begin{array}{l}+ \\
+\end{array}$ & $\begin{array}{l}\text { Taylor-Robinson, Harrow } \\
\text { Own isolation (monkey) }\end{array}$ \\
\hline M. fermentans & G2 & $\mathrm{c} 2$ & + & Lab. Hyg. Amsterdam \\
\hline M. hominis & $\begin{array}{l}\text { V37 } \\
\text { KB§ } \\
\text { PG21 } \\
\text { VKL312 } \\
\text { P42 } \\
\text { M15 }\end{array}$ & $\begin{array}{l}\mathrm{c} 3 \\
\mathrm{c} 4 \\
\mathrm{c5} \\
\mathrm{c13} \\
\mathrm{c14} \\
\mathrm{c15}\end{array}$ & $\begin{array}{l}\overline{+} \\
\overline{+} \\
\overline{+} \\
-\end{array}$ & $\begin{array}{l}\text { Lab. Hyg. Amsterdam } \\
\text { Own isolation (cell culture) } \\
\text { NCTC* } \\
\text { v. Klingeren, Utrecht } \\
\text { Own isolation (human) } \\
\text { Sturm, Amsterdam }\end{array}$ \\
\hline M. orale & $\begin{array}{l}\text { Hilverda } \\
\text { RIV§ }\end{array}$ & $\begin{array}{l}\text { c6 } \\
\text { c7 }\end{array}$ & $\overline{+}$ & $\begin{array}{l}\text { Lab. Hyg. Amsterdam } \\
\text { Own isolation (cell culture) }\end{array}$ \\
\hline $\begin{array}{l}\text { M. pneumoniae } \\
M . \text { primatum }\end{array}$ & $\begin{array}{l}\text { Mac } \\
\text { Navel } \\
\text { CynV4a } \mid\end{array}$ & $\begin{array}{l}\mathrm{c} 8 \\
\mathrm{c} 9 \\
\mathrm{c} 12\end{array}$ & $\begin{array}{l}+ \\
+ \\
-\end{array}$ & $\begin{array}{l}\text { Hers, Leiden } \\
\text { Lab. Hyg. Amsterdam } \\
\text { Own isolation (monkey) }\end{array}$ \\
\hline M. salivarium & PG20 & $\mathrm{c} 10$ & + & NCTC* \\
\hline M. hyorhinis & GDL & d1 & + (i.v.) & Leach, London \\
\hline
\end{tabular}

(i.v.), Intravenous injections followed by the normal immunization scheme.

* Strains received via the Laboratory of Hygiene (Lab. Hyg.), Amsterdam; $\dagger$ Animal Health Research Laboratory, Melbourne; $¥$ identified by R. H. Leach, Mycoplasma Reference Laboratory, Colindale, London; § identified by A. Charlotte Ruys, former head of Lab. Hyg., Amsterdam; || identified by Auriol Hill, Carshalton.

\section{METHODS}

Strains. The strains examined (see Table 1) included isolates from cell cultures, cattle, humans and monkeys.

Media. 'Herderscheê medium' (Herderscheê, 1963) was used for isolation and subcultivation. This medium contained beef heart broth, proteose peptone $(1 \%, \mathrm{w} / \mathrm{v})$, sucrose $(7 \%, \mathrm{w} / \mathrm{v})$, defibrinated boiled sheep blood $(5 \%, v / v)$, heated horse serum $\left(20 \%, v / v ; 30\right.$ min at $\left.56{ }^{\circ} \mathrm{C}\right)$, acid filtered yeast extract $(10 \%, \mathrm{w} / \mathrm{v}$; Hers \& Masurel, 1967) and ampicillin $\left(500 \mu \mathrm{g} \mathrm{ml}^{-1}\right), \mathrm{pH} \mathrm{7.7}$; solid medium was prepared by adding purified agar 
$(0.9 \%, \mathrm{w} / \mathrm{v} ;$ Oxoid L 28). The mycoplasma strains used for the preparation of antisera were cultivated, after cloning, during four passages in a medium in which rabbit blood and rabbit serum and cholesterol $(0.01 \%$, w/v) (Edward \& Fitzgerald, 1951) were added to the basal medium instead of sheep blood and horse serum.

Where possible the strains for the serological tests were cultivated on Difco PPLO medium with heated horse serum $(20 \%, \mathrm{v} / \mathrm{v})$ and acid yeast extract $(10 \%, \mathrm{w} / \mathrm{v})$. Difco PPLO medium supplemented with yeast extract $(10 \%, \mathrm{w} / \mathrm{v})$ but without serum was also used for the identification of acholeplasmas.

Preparation of antisera. Concentrated washed mycoplasma suspensions in saline $(0.15 \mathrm{M})$ were prepared and stored at $-70^{\circ} \mathrm{C}$. Prior to injection, the suspensions were adsorbed to $\mathrm{AlPO}_{4}\left(3 \mathrm{mg} \mathrm{ml}{ }^{-1}\right.$, prepared 'in situ') and emulsified in an equal volume of complete Freund's adjuvant (CFA, Difco). One ml of this mixture was injected intramuscularly into each of three rabbits of the $F_{1}$ generation of Flemish giants $\times$ Danish whites; after 4 weeks a second intramuscular injection was given with a $5 \mathrm{ml}$ mycoplasma suspension adsorbed to $\mathrm{AlPO}_{4}\left(3 \mathrm{mg} \mathrm{ml}^{-1}\right)$ without CFA. Blood was taken 5 to $6 \mathrm{~d}$ after the second injection and the sera were tested in the growth inhibition test. When the antibody titre was too low, a series of intravenous injections was given with antigen minus additions starting 4 weeks after the second injection (see Table 1). When the antibody titre was satisfactory, the rabbits were bled $10 \mathrm{~d}$ after the final injection. The sera were stored at $-20{ }^{\circ} \mathrm{C}$; before use they were held at $56^{\circ} \mathrm{C}$ for $30 \mathrm{~min}$. The strains against which antisera were prepared are shown in Table 1.

Preparation of sheep-antirabbit IgG-peroxidase conjugate. A sheep was immunized with $1.3 \mathrm{mg}$ rabbit IgG in CFA and blood was taken after $24 \mathrm{~d}$. The IgG fraction of the antiserum was isolated after precipitation of the other proteins with caprylic acid (Steinbuch \& Audran, 1969), dialysed against $\mathrm{NaCl}(0.15 \mathrm{M})$ and lyophilized. Horseradish peroxidase (Sigma, type VI) was conjugated to this fraction by the method of Nakane \& Kawaoi (1974) but without the final addition of $\mathrm{NaBH}_{4}$. The conjugate was purified by Sephadex G-200 gel filtration and the excluded fraction was used. One hour before use in the IP test the conjugate was diluted $1: 5$ in bovine serum albumin $(0.5 \%$, w/v) with Tween $80(0.01 \%, \mathrm{w} / \mathrm{v})$.

Preparation of fluorescent horse-antirabbit IgG conjugate. The immunoglobulin fraction of a horse antiserum directed against rabbit IgG was conjugated with fluorescein isothiocyanate (FITC) (The \& Feltkamp, 1970). The conjugate was used in a 1:20 dilution in phosphate-buffered saline (PBS), pH 7.1.

Indirect immunological tests. Unfixed colonies on agar blocks were used (Rosendal \& Black, 1972). Starting from $1: 10$ antiserum dilutions in broth, twofold serial dilutions in broth were prepared. Pre-immunization sera were tested in 1:10 dilution only.

Agar blocks with separate colonies were placed in Petri dishes and incubated for $30 \mathrm{~min}$ at room temperature with a drop of antiserum dilution. The blocks were then gently washed twice with PBS for 10 min, incubated for $30 \mathrm{~min}$ at room temperature with a drop of the conjugate dilution and washed twice with PBS for $15 \mathrm{~min}$.

The immunofluorescence (IF) and immunoperoxidase (IP) tests were carried out simultaneously using blocks of the same agar culture and identical antiserum dilutions. When several strains and antisera were compared in serum dilution experiments, agar cultures of the same age were used (usually 3 to $4 \mathrm{~d}$ old). The highest antiserum dilution giving a positive reaction was considered to be the endpoint titre.

Reading the IP test. The colonies were treated with a few drops of a 3,3'-diaminobenzidine tetrahydrochloride solution $(0.06 \%, \mathrm{w} / \mathrm{v})$ in Tris/HCl buffer $(0.6 \%, \mathrm{w} / \mathrm{v})$ with hydrogen peroxide $(0.1 \%, \mathrm{v} / \mathrm{v})$ (Graham \& Karnovsky, 1966). This substrate forms a dark brown precipitate on the colonies in the presence of the enzyme. The blocks were examined under a light microscope $(40 \times$ or $100 \times)$ in Petri dishes; agar blocks treated with none, one or two of each of the three reagents (antiserum, conjugate and diaminobenzidine plus $\mathrm{H}_{2} \mathrm{O}_{2}$ ) served as controls.

Reading the IF test. After treatment with FITC-conjugate, the blocks were put on slides for the final microscopic examination $(100 \times$ or $250 \times)$. They were illuminated with incident light from a mercury lamp, filtered through a Leitz Ploemopak filter system for FITC $(490 \mathrm{~nm})$. As controls, one agar block was left untreated and either the antiserum or the conjugate was omitted from another two.

Growth inhibition (GI) test. The filter paper disc method was applied (Clyde, 1964). When the results were dubious, the agar well technique was used (Black, 1973). Pre-immunization sera were tested undiluted.

\section{RESULTS}

Colonies on agar blocks treated with homologous antiserum showed a distinct brown colour whereas those treated with heterologous antisera did not change colour. Colonies in mixed cultures were easily distinguished (Figs 1 and 2).

The controls in the IP test were negative. However, occasionally the centres of untreated colonies of Mycoplasma bovirhinis were brown, which sometimes caused problems in reading the reactions when this type was present in mixed cultures. 


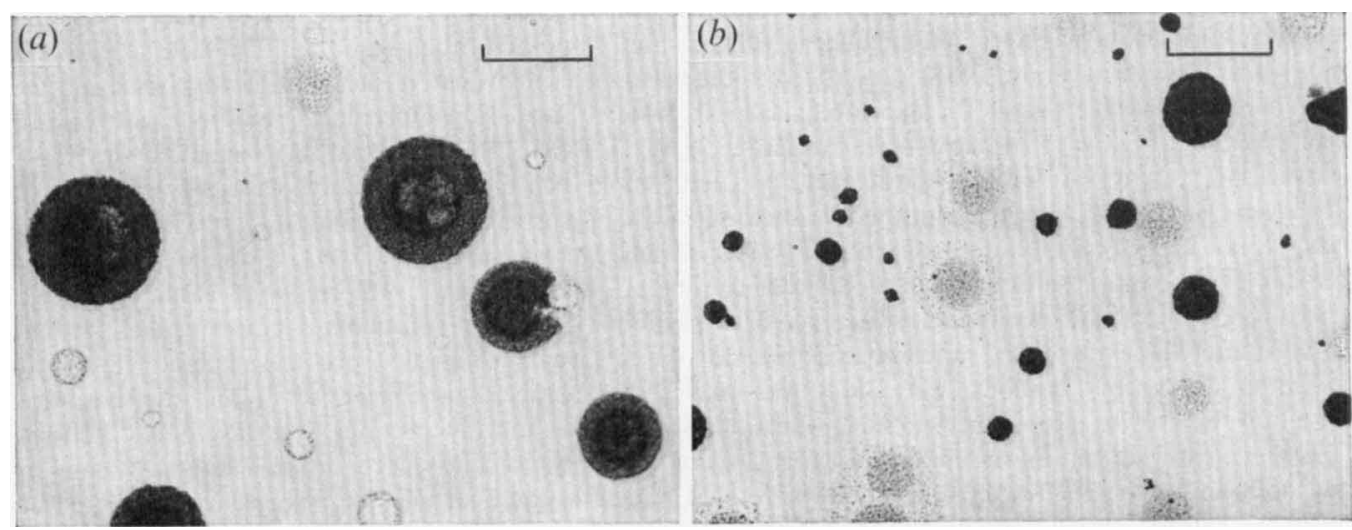

Fig. 1. Mixed cultures of Acholeplasma laidlawii and A. modicum (cultures deliberately mixed). (a) Treated with a 1:10 dilution of antiserum against $A$. laidlawii. (b) Treated with a 1:10 dilution of antiserum against $A$. modicum. Bar markers represent $0.1 \mathrm{~mm}$.
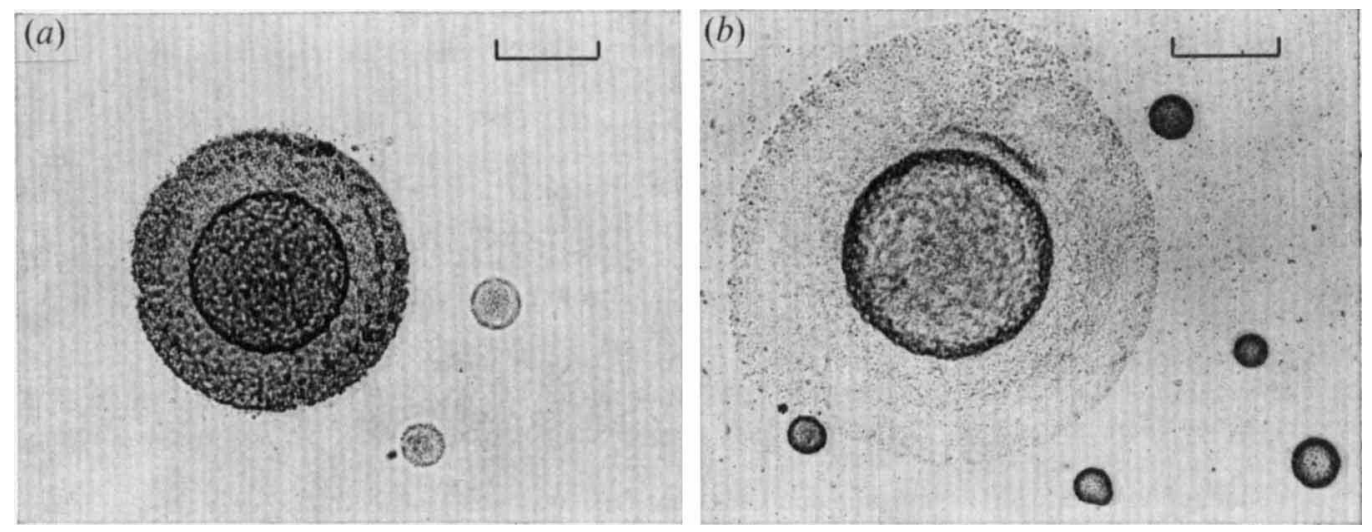

Fig. 2. Mixed culture isolated from cell cultures. (a) Treated with a 1:10 dilution of antiserum against $M$. arginini. (b) Treated with a 1:10 dilution of antiserum against $M$. orale. Bar markers represent $0.1 \mathrm{~mm}$.

In the IF test untreated colonies of Acholeplasma laidlawii, A. modicum, M. agalactiae and $M$. bovis strains showed a bright yellow autofluorescence which hampered the reading of the green-yellow immunofluorescence, and in these cases the results were ignored. The autofluorescence depended neither on the presence of serum in the medium nor on the age of the colonies.

Acholeplasma and animal mycoplasma strains. In each of the three serological tests, these strains were examined with homologous and heterologous antisera. For most strains the specificities of the tests were in good agreement (Table 2), but five anomalies were found. In four cases the GI test was negative while the IP (and IF) tests were positive (Tables 3 and 4); $M$. agalactiae and $M$. bovis were not examined using the IF test. Sometimes high titres were obtained in the IP and IF tests with antisera which caused only a slight or no growth inhibition of homologous strains (PG11, Table 4).

The fifth anomaly obtained with antisera against two $A$. axanthum strains was different. In these cases the IP test was negative and the GI and IF tests were positive (Table 5). Cultivation of the organisms on medium without serum improved the results with the antiserum against strain s743 (a1), but not with the antiserum against KN349 (a6). Two other $A$. axanthum strains (KN344 and KN671) isolated from the nasopharynx of new-born 
Table 2. Comparison of the specificities of the growth inhibition (GI), immunoperoxidase (IP) and immunofluorescence (IF) tests for the identification of acholeplasmas and animal mycoplasmas

Antiserum

Type and code no.

\begin{tabular}{|c|c|c|c|c|c|c|c|c|c|c|c|c|c|c|c|}
\hline 1 & a6 & a2 & a3 & a5 & b1 & b2 & b3 & b4 & b5 & b6 & b9 & b10 & b) & b12 & $\mathrm{d} 1$ \\
\hline & $\mathrm{x}$ & - & - & - & - & - & - & - & - & - & - & - & - & 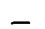 & _ \\
\hline & + & - & - & - & - & - & - & - & - & - & - & - & - & & NT \\
\hline & - & + & - & - & - & - & - & - & - & - & - & - & - & - & - \\
\hline & - & - & + & - & - & - & - & - & - & - & - & - & - & - & - \\
\hline & - & - & - & + & - & - & - & - & - & - & - & - & - & - & - \\
\hline & - & - & - & - & + & - & - & - & - & \pm & - & - & - & - & NT \\
\hline & - & - & - & - & - & + & - & - & - & $=$ & - & - & - & - & NT \\
\hline & - & - & - & - & - & - & + & - & - & - & - & - & - & - & - \\
\hline & - & - & - & - & - & - & - & + & - & - & - & - & - & - & $\mathrm{NT}$ \\
\hline & - & - & - & - & - & - & - & \pm & - & - & - & - & - & - & NT \\
\hline & - & - & - & - & - & - & - & & + & - & - & - & - & - & - \\
\hline & - & - & - & - & \pm & - & - & - & - & + & - & - & - & - & NT \\
\hline & - & - & - & - & - & - & - & - & - & - & + & - & - & - & - \\
\hline & - & - & - & - & - & - & - & - & - & - & - & + & - & - & NT \\
\hline & - & - & - & - & - & - & - & - & - & - & - & - & + & + & - \\
\hline & - & - & - & - & - & - & - & & - & - & - & - & \pm & + & - \\
\hline & NT & - & - & - & NT & NT & - & NT & - & NT & - & NT & - & - & + \\
\hline
\end{tabular}

A. axanthum a1
a6*
(6.

A. granularum a2

A. laidlawii a3, 4, 7, 8 (F)

A. modicum a5 (F)

$M$. agalactiae b1 (F)

M. alkalescens b2

$M$. arginini b3

$M$. bovigenitalium b4

$M$. bovirhinis b5

b13

M. bovis b6, 7, 14 (F)

M. bovoculi $\mathrm{b} 8,9$

M. equirhinis b10, 15

$M$. mycoides b11, 16

Mycoplasma sp. group 7 b12

M. hyorhinis $\mathrm{d} 1$

* Tested on medium without serum. (F), Controls showed autofluorescence, IF test not performed.

+ , All tests positive; \pm , GI test negative, other test(s) positive; $x$, IP test negative, other tests positive; - , all tests negative; NT, not tested.

Table 3. Comparison of $M$. agalactiae and M. bovis in the GI and IP tests

\begin{tabular}{|c|c|c|c|c|c|c|}
\hline \multirow[b]{3}{*}{ Type and strain } & \multicolumn{6}{|c|}{ Antiserum } \\
\hline & \multicolumn{2}{|c|}{$\mathrm{PG} 2$} & \multicolumn{2}{|c|}{ Donetta } & \multicolumn{2}{|c|}{ KN186 } \\
\hline & GI & IP & GI & IP & GI & IP \\
\hline $\begin{array}{c}\text { M. agalactiae } \\
\text { PG2 (b1) }\end{array}$ & ++ & $12 \cdot 3$ & - & $4 \cdot 3$ & - & $5 \cdot 3$ \\
\hline M. bovis & & & & & & \\
\hline Donetta (b6) & - & $3 \cdot 3$ & + & $6 \cdot 3$ & + & $9 \cdot 3$ \\
\hline KN186 (b7) & - & $4 \cdot 3$ & \pm & $5 \cdot 3$ & + & $10 \cdot 3$ \\
\hline H16 (b14) & - & $<3.3$ & $\bar{t}$ & $5 \cdot 3$ & + & $6 \cdot 3$ \\
\hline
\end{tabular}

GI test (undiluted serum), inhibition: ++ , total; + , near total; \pm , weak; - , none.

IP test: titres in $\log _{2}$ starting from $1: 10$ dilution $(=3 \cdot 3)$.

Table 4. Comparison of $M$. mycoides, Mycoplasma sp. group 7 and $M$. bovigenitalium in the GI, IP and IF tests

\begin{tabular}{|c|c|c|c|c|c|c|c|c|c|}
\hline \multirow[b]{3}{*}{ Type and strain } & \multicolumn{9}{|c|}{ Antiserum } \\
\hline & \multicolumn{3}{|c|}{ Gladysdale } & \multicolumn{3}{|c|}{ N29 } & \multicolumn{3}{|c|}{ PG11 } \\
\hline & GI & IP & IF & GI & IP & IF & GI & IP & IF \\
\hline $\begin{array}{l}\text { M. mycoides } \\
\text { Gladysdale (b11) } \\
\text { PP (b16) }\end{array}$ & $\begin{array}{l}+ \\
+\end{array}$ & $\begin{array}{l}6 \cdot 3 \\
8 \cdot 3\end{array}$ & $\begin{array}{l}5 \cdot 3 \\
7 \cdot 3\end{array}$ & $\begin{array}{l}+ \\
+\end{array}$ & $\begin{array}{l}4 \cdot 3 \\
6 \cdot 3\end{array}$ & $\begin{array}{l}5 \cdot 3 \\
8 \cdot 3\end{array}$ & $\begin{array}{l}- \\
-\end{array}$ & $\begin{array}{l}<3 \cdot 3 \\
<3 \cdot 3\end{array}$ & $\begin{array}{l}<3 \cdot 3 \\
<3 \cdot 3\end{array}$ \\
\hline $\begin{array}{l}\text { Mycoplasma sp. group } 7 \\
\text { N29 (b12) }\end{array}$ & - & $7 \cdot 3$ & $7 \cdot 3$ & ++ & $9 \cdot 3$ & $10 \cdot 3$ & - & $<3.3$ & $<3 \cdot 3$ \\
\hline $\begin{array}{l}\text { M. bovigenitalium } \\
\text { PG11 (b4) } \\
\text { RN117 (b13) }\end{array}$ & $\begin{array}{l}- \\
-\end{array}$ & $\begin{array}{l}<3.3 \\
<3.3\end{array}$ & $\begin{array}{l}<3.3 \\
<3.3\end{array}$ & - & $\begin{array}{l}<3.3 \\
<3.3\end{array}$ & $\begin{array}{l}<3.3 \\
<3.3\end{array}$ & \pm & $\begin{array}{r}9 \cdot 3 \\
11 \cdot 3\end{array}$ & $\begin{array}{l}10 \cdot 3 \\
11 \cdot 3\end{array}$ \\
\hline
\end{tabular}

GI test (undiluted serum), inhibition: ++ , total; + , near total; \pm , weak; - , none. IP and IF tests: titres in $\log _{2}$ starting from $1: 10$ dilution $(=3 \cdot 3)$. 
Table 5. Comparison of A. axanthum strains in the GI, IP and IF tests

\begin{tabular}{|c|c|c|c|c|c|c|}
\hline \multirow{3}{*}{ Strain } & \multicolumn{6}{|c|}{ Antiserum } \\
\hline & \multicolumn{3}{|c|}{ s743 } & \multicolumn{3}{|c|}{ KN349 } \\
\hline & GI & IP & IF & GI & IP & IF \\
\hline s743 (a1) & ++ & $8 \cdot 3$ & $9 \cdot 3$ & ++ & $<3.3$ & $9 \cdot 3$ \\
\hline s743* & ++ & $8 \cdot 3$ & $8 \cdot 3$ & ++ & $<3.3$ & $8 \cdot 3$ \\
\hline KN349 (a6) & ++ & $<3 \cdot 3$ & $9 \cdot 3$ & ++ & $5 \cdot 3$ & $11 \cdot 3$ \\
\hline KN349* & ++ & $5 \cdot 3$ & $6 \cdot 3$ & ++ & $6 \cdot 3$ & $10 \cdot 3$ \\
\hline KN344 & ++ & $<3.3$ & $8 \cdot 3$ & $+t$ & $<3 \cdot 3$ & $4 \cdot 3$ \\
\hline $\mathrm{KN} 344^{*}$ & ++ & $3 \cdot 3$ & $4 \cdot 3$ & ++ & $<3 \cdot 3$ & $3 \cdot 3$ \\
\hline KN671 & ++ & $<3 \cdot 3$ & $5 \cdot 3$ & ++ & $<3.3$ & $3 \cdot 3$ \\
\hline KN671* & $t+$ & $3 \cdot 3$ & $4 \cdot 3$ & ++ & $<3 \cdot 3$ & $3 \cdot 3$ \\
\hline
\end{tabular}

Table 6. Comparison of the specificities of the GI, IP and IF tests for the identification of human and primate mycoplasmas

\begin{tabular}{|c|c|c|c|c|c|c|c|c|c|}
\hline \multirow[b]{2}{*}{ Type and code no. } & \multicolumn{9}{|c|}{ Antiserum } \\
\hline & c1 & c11 & $\mathrm{c} 2$ & $c 4$ & c7 & c8 & c9 & $\mathrm{c} 10$ & d1 \\
\hline M. buccale $\mathrm{cl}$ & + & \pm & - & - & - & - & - & - & NT \\
\hline c11 & + & $\bar{t}$ & - & - & - & - & - & - & NT \\
\hline M. fermentans $\mathrm{c} 2 *$ & - & - & + & - & - & - & - & - & - \\
\hline M. hominis c3, $4,5,13,14$ & - & - & - & + & - & - & - & - & - \\
\hline $\mathrm{c} 15$ & - & - & - & \pm & - & - & - & - & NT \\
\hline M. orale $\mathrm{c} 6,7$ & - & - & - & $\overline{-}$ & + & - & - & - & - \\
\hline M. pneumoniae c8 & - & - & - & - & - & + & - & - & NT \\
\hline M. primatum c9, $12^{*}$ & - & - & - & - & - & - & + & - & NT \\
\hline$M$. salivarium $\mathrm{c} 10$ & - & - & - & - & - & - & - & + & - \\
\hline M. hyorhinis d1 & NT & NT & - & - & - & NT & NT & - & + \\
\hline
\end{tabular}

* Tested on boiled blood medium.

+ , All tests positive; \pm , GI test negative, other tests positive; -, all tests negative; NT, not tested.

Table 7. Comparison between two antisera against different strains of the same type (M. buccale and M. hominis)

Type and strain

\begin{tabular}{|c|c|c|c|c|c|}
\hline \multicolumn{6}{|c|}{ Antiserum } \\
\hline \multicolumn{3}{|c|}{ PG41 } & \multicolumn{3}{|c|}{ CynK1 } \\
\hline GI & IP & IF & GI & IP & IF \\
\hline+ & $11 \cdot 3$ & $11 \cdot 3$ & - & $8 \cdot 3$ & $8 \cdot 3$ \\
\hline \pm & $10 \cdot 3$ & $10 \cdot 3$ & + & $10 \cdot 3$ & $10 \cdot 3$ \\
\hline \multicolumn{3}{|c|}{$\mathbf{K B}$} & \multicolumn{3}{|c|}{ VKL312 } \\
\hline GI & IP & IF & GI & IP & IF \\
\hline++ & $12 \cdot 3$ & $12 \cdot 3$ & + & $9 \cdot 3$ & $10 \cdot 3$ \\
\hline \pm & $10 \cdot 3$ & $9 \cdot 3$ & ++ & $12 \cdot 3$ & $12 \cdot 3$ \\
\hline+ & $9 \cdot 3$ & $9 \cdot 3$ & + & $10 \cdot 3$ & $9 \cdot 3$ \\
\hline+ & $10 \cdot 3$ & $9 \cdot 3$ & + & $10 \cdot 3$ & $10 \cdot 3$ \\
\hline \pm & $9 \cdot 3$ & $9 \cdot 3$ & + & $8 \cdot 3$ & $8 \cdot 3$ \\
\hline- & $7 \cdot 3$ & $9 \cdot 3$ & - & $9 \cdot 3$ & $10 \cdot 3$ \\
\hline
\end{tabular}

M. buccale

PG41 (c1)

CynK1 (c11)

M. hominis

KB (c4)
VKL312 (c13)
V37 (c3)
PG21 (c5)
P42 (c14)
M15 (c15)

GI test (undiluted serum), inhibition: ++ , total; + , near total; \pm , weak; - , none.

IP and IF tests: titres in $\log _{2}$ starting from $1: 10$ dilution $(=3 \cdot 3)$. 
calves were examined with both antisera; they reacted slightly with anti-s743 serum in the IP test but not at all with anti-KN349 serum.

Human and primate mycoplasmas. These strains were also examined with the homologous and heterologous antisera (Table 6) and two discrepancies found (Table 7). Two anti- $M$. hominis sera were used, one against a strain isolated from cell cultures (KB) and one against a strain isolated from a human (VKL312); both antisera gave corresponding results. One strain (M15) was not inhibited by either antiserum, though it reacted positively in the IP and IF tests with these antisera. Furthermore, a strain isolated from the oropharynx of a monkey (CynK1) cross-reacted in the IP and IF tests with a human strain of $M$. buccale (PG41). In the GI test, CynK1 was only slightly inhibited by antiserum against PG41, and PG41 was not inhibited by anti-CynK1-serum (Table 7). Mycoplasma hyorhinis can be found as a cell culture contaminant and was therefore compared not only with the porcine type A. granularum, but also with the other acholeplasma types, and with some human and animal mycoplasma types which can be detected in cell cultures. It was also cross-tested with a few other glucose converting types (Tables 2 and 6). No cross-reactions were found.

\section{DISCUSSION}

Comparison of the IP and IF tests showed that each has its limitations. In the IF test the untreated colonies of $A$. laidlawii, A. modicum, $M$. agalactiae and $M$. bovis showed a bright yellow autofluorescence, and discrimination between immunofluorescence and autofluorescence was impossible, as has been found previously (Potgieter \& Ross, 1972). All other controls were negative. The controls of the IP test were also negative. However, sometimes the centres of $M$. bovirhinis colonies were brown although this did not seriously interfere with the reading of the reaction. In most cases the IP test was as sensitive as the IF test but trouble was encountered in the identification of some $A$. axanthum strains isolated from new-born calves. It is not clear at present why the two techniques, based on the same principles, lead to such widely different results. The reactions of the $A$. axanthum colonies in the IP test were better on Difco PPLO medium without serum than on medium with serum (Table 5). The reaction of $A$. laidlawii colonies was also more pronounced on medium without serum. This might be due to the fact that the agar concentration was higher in the medium without serum, leading to smaller but more compact colonies. Very large, flat $A$. laidlawii colonies coloured only pale brown in the IF test. It remains to be seen whether an increase in the agar concentration in the medium, without changing the serum concentration, will also improve the reactions of these acholeplasma types. In both the IP and IF tests, very large colonies had to be washed gently otherwise the upper parts of the colonies tended to peel off, a problem also noted by Al-Aubadi \& Fabricant (1971).

Mycoplasma types such as $M$. fermentans and $M$. primatum could not be cultivated on Difco PPLO medium, and for these, boiled-blood extract medium was used. For other mycoplasma types the results obtained with the IP and IF tests were the same irrespective of the medium used, but the results with the GI test were usually better on Difco medium.

The IP test had about the same specificity as the IF and GI tests though there were anomalies. In some cases the GI test was negative whereas the reactions in the IP and IF tests were positive. These discrepancies might be caused either by the low sensitivity or by a high specificity of the GI test. For instance, a human and a primate $M$. buccale strain showed only a slight one-way cross-reaction in the GI test, although in the IP and IF tests they were clearly shown to be related (Table 7). Similarly a $M$. hominis strain reacted in the IP and IF tests, but not in the GI test, with two anti- $M$. hominis sera (Table 7). This might be due to strain differences. Mycoplasma agalactiae PG2 and $M$. bovis strains Donetta and KN186 cross-reacted in the IP test but not in the GI test (Table 3). These two types also share the property of autofluorescence and other biochemical characters (Ernø \& Stipkovits, 1973; Leach, 1973). At one time the Donetta and related bovine strains were considered to 
be subspecies of M. agalactiae (Ernø \& Jurmanová, 1973; Leach, 1973). However, Askaa \& Ernø (1976) showed that the DNA homology values between Donetta and PG2 were too low for them to be classified in the same genospecies and the Donetta-like strains were classified as $M$. bovis. The results in the IP test with these two types, therefore, suggest that the test is not as specific as the GI test.

Cross-reactions were also seen in the IP and IF tests between $M$. mycoides strain Gladysdale and group 7 strain N29 (Leach, 1967) (Table 4). The anti-Gladysdale serum did not inhibit the growth of $\mathrm{N} 29$, but the anti-N29 serum did inhibit the Gladysdale strain. A third strain (PP) was inhibited by both antisera and also reacted with these sera in the IP and IF tests. The relationship found between Leach's (1967) group 7 and M. mycoides has also been reported by other workers (Ernø \& Jurmanová, 1973; Leach, 1973; Askaa \& Ernø, 1974; Jurmanová, Hájková \& Černá, 1976). However, cross-reactions found between group 7 and $M$. bovigenitalium, M. agalactiae or $M$. arginini (Cottew, 1970; Ernø \& Jurmanová, 1973; Ernø, Jurmanová \& Leach, 1973) were not confirmed in the present study. Cross-reactions were not found between any of the other human and animal mycoplasma and acholeplasma types.

Isolates from cattle, cell cultures, humans and monkeys were easily identified with the IP test. In mixed cultures it was simple to differentiate colonies treated with homologous antiserum from unstained colonies using a normal light microscope. It is, therefore, much easier to read the results of the IP test than those of the IF test. The age of the cultures did not influence the results, and cultures up to 4 weeks old could still be used provided they were not completely covered with 'spots' (Edward, 1950). Fully treated agar blocks could still be read when stored for at least 1 week at $4{ }^{\circ} \mathrm{C}$.

From the present observations we conclude that the IP test can be used for the identification of Mycoplasmatales, and for strains which autofluoresce the IP test is preferable to the IF test.

Thanks are due to Miss Betsy Kuipers and Mrs Yvonne de Lange-Folmer for their assistance in preparing the conjugates, and to Mr Reygers for his technical help with the serological tests and for the preparation of antisera.

\section{REFERENCES}

Al-Aubadi, J. M. \& Fabricant, J. (1971). The practical application of immunofluorescence (agar block technique) for the identification of $\mathrm{Myco}$ plasma. Cornell Veterinarian 61, 519-542.

AsKAA, G. \& ERNø, H. (1974). Genetic relatedness among biochemical and serological related mycoplasmas. Abstracts Volume, International Congress on Mycoplasmas of Man, Animals, Plants and Insects, Bordeaux, p. 7.

AskAA, G. \& ERNø, H. (1976). Elevation of Mycoplasma agalactiae subsp. bovis to species rank: Mycoplasma bovis (Hale et al.) comb. nov. International Journal of Systematic Bacteriology 26, 323-325.

BLACK, F. T. (1973). Modification of the growth inhibition test and its application to human T-mycoplasmas. Applied Microbiology 25, 528533.

Carski, T. R. \& Shepard, C. C. (1961). Pleuropneumonia-like (mycoplasmas) infections of tissue culture. Journal of Bacteriology 85, 626-635.

CLYde, W. A. (1964). Mycoplasma species identification based upon growth inhibition by specific antisera. Journal of Immunology 92, 958-965.

CotTew, G. S. (1970). Mycoplasmas isolated from cattle in Australia. Australian Veterinary Journal 46, 378-381.

Del Giudice, R. A., Robillard, N. F. \& Carski, T. R. (1967). Immunofluorescence identification of Mycoplasma on agar by use of incident illumination. Journal of Bacteriology 93, 12051209.

EDWARD, D. G. FF. (1950). An investigation of pleuropneumonia-like organisms isolated from the bovine genital tract. Journal of General Microbiology 4, 4-15.

Edward, D. G. FF. \& Fitzgerald, W. A. (1951). Cholesterol in the growth of organisms of the pleuropneumonia group. Journal of General Microbiology 5, 576-586.

Edward, D. G. FF. \& FitzGerald, W. A. (1954). Inhibition of growth of pleuropneumonia-like organisms by antibody. Journal of Pathology and Bacteriology 68, 23-30.

ERnø, H. \& Jurmanová, K. (1973). Bovine mycoplasmas: serological studies by double immunodiffusion, growth precipitation and growth inhibition. Acta veterinaria scandinavica 14, 524-537.

ERnø, H. \& Stipkovits, L. (1973). Bovine myco- 
plasmas: cultural and biochemical studies. II. Acta veterinaria scandinavica 14, 450-463.

Ernø, H., Jurmanová, K. \& LeaCH, R. H. (1973). Bovine mycoplasmas: a serological study by the metabolic inhibition test. Acta veterinaria scandinavica 14, 511-523.

GraHAM, R. \& KaRnovsKy, M. (1966). The early stages of absorption of injected horseradish peroxidase in the proximal tubule of mouse kidney: ultrastructural cytochemistry by a new technique. Journal of Histochemistry and Cytochemistry 14, 291-306.

Herderschêt, D. (1963). An improved medium for the cultivation of the Eaton agent. Antonie van Leeuwenhoek 29, 154-156.

Hers, J. F. Ph. \& Masurel, N. (1967). Infection with Mycoplasma pneumoniae in civilians in the Netherlands. Annals of the New York Academy of Sciences 143, 447-460.

Huysmans-Evers, A. G. \& Ruys, A. C. (1956). Microorganisms of the pleuropneumonia group (family of Mycoplasmataceae) in man. II: Serological identification and discussion of pathogenicity. Antonie van Leeuwenhoek 22, 377-384.

Jurmanová, K., HáJková, M. \& Černá, J. (1976). Serological studies of bovine mycoplasmas. II. Determination of taxonomical relatedness by means of seven tests. Zentralblatt für Veterinärmedizin B23, 59-65.

LEACH, R. H. (1967). Comparative studies of myco- plasmas of bovine origin. Annals of the New York Academy of Sciences 143, 305-316.

LEACH, R. H. (1973). Further studies on classification of bovine strains of Mycoplasmatales, with proposals for new species, Acholeplasma modicum and Mycoplasma alkalescens. Journal of General Microbiology 75, 135-153.

Malizia, W. F., Barile, M. F. \& Riggs, D. B. (1961). Immunofluorescence of pleuropneumonialike organisms isolated from tissue cell cultures. Nature, London 191, 190-191.

Nakane, P. K. \& KawaoI, A. (1974). Peroxidaselabeled antibody. A new method of conjugation. Journal of Histochemistry and Cytochemistry 22, 1084-1091.

Potgieter, L. N. D. \& Ross, R. F. (1972). Identification of Mycoplasma hyorhinis and Mycoplasma hyosynoviae by immunofluorescence. American Journal of Veterinary Research 33, 91-98.

Rosendal, S. \& BLACK, F. T. (1972). Direct and indirect immunofluorescence of unfixed and fixed mycoplasma colonies. Acta pathologica et microbiologica scandinavica B80, 615-622.

Steinbuch, M. \& AUdRAN, R. (1969). The isolation of IgG from mammalian sera with the aid of caprylic acid. Archives of Biochemistry and Biophysics 134, 279-284.

The, T. H. \& FeltKamp, T. E. W. (1970). Conjugation of fluorescein isothiocyanate to antibodies. I: Experiments on condition of conjugation. Immunology 18, 865-873. 